\title{
Socio-Pragmatic Errors and Their Pedagogical Implication in ELT
}

\author{
Hieronimus Canggung Darong \\ Universitas Katolik Indonesia Santu Paulus \\ \{hieronimusdarong@gmail.com\}
}

\begin{abstract}
The socio-pragmatic error is concerned with the deviation of form and meaning in the target language. Regardless of other types, such as grammatical and lexical errors focusing on sound, lexeme and sentence order or any syntactical pattern (microlinguitics), socio-pragmatic error is an error in which context of the language user is definitely involved (macrolinguitics). It deals with what is common and acceptable in a certain community and what is not. The acceptability is closely related to an understanding of the context where language is being used. Referring to the statements in question, the main objective of this article was to describe the observed Indonesian daily speakers' conversations socio-pragmatic errors. Conversation analysis supporting by pragmatic perspective was used to analyze the data. The results of analysis indicated that the L1 interference and insufficient knowledge of context and culture of the target language (L2) caused the socio-pragmatic errors. As such, the results might of benefit in English Language Teaching (ELT) as highlighted at the end of this article.
\end{abstract}

Keywords: Socio-pragmatic errors; implication; ELT

\section{Introduction}

English learners might still struggle with the mastery of basic linguistic forms which mostly lead to errors. As such, the errors are concerned with deviation of meaning and form resulting from first language (L1) transfer into target language (L2). Along the line of this statement, the errors, in fact, occur as having insufficient knowledge of target language and target culture. They are considerably influenced by and focused on the real practice or socio-culture norms existing within society. The deviation of form and meaning of L1 transfer is always a central issue in the target language (L2) production.

Having pointed out the deviation of meaning and form (errors), a great number of studies has been carried out. Interestingly, previous studies have come up with several perspectives. For example, English learners tend to have grammatical or syntactical errors in both writing and oral production [1]-[9]. In this respect, the researchers carried out the studies as the wish of coping with what and how the errors are. Aside from what and how, the interest seems to reveal more specific on what is good and what is not; acceptable or not referring to the norms of the target language.

Stressing on morphological and lexical errors, other studies have shed light on the manner in which students internalize the rules of the target language and subsequently lead them to communication breakdowns [10]-[14]. Likely, in the studies of [15] and [16] the reasons of the errors in question are highly related to the L1 transfer. As such, they are not only reflected in 
the word's choice, phrases construction, paragraphs building but also in spoken mode. Furthermore, what is taken into account of those in question is that the language production closely relates to the transfer of linguistic forms of L1 into L2

However, a cautionary note is necessary here. The cause of errors does not only deal with linguistic forms ( $\mathrm{L} 1$ to L2) but also the culture transfer of L1 users to the culture of L2 (target language) users. In this regard, there should be an emphasis that culture and language is definitely related. Without culture, language would be dead, and without language culture would have no shape [17]. They are so interwoven that separating one from the other would lose the significance of the other [18], [19]. To add on, a study of [20] has emphasized that language is something socially shared meaning system. In this regard, the characteristics of language is socially shared. The meaning of language is not on the language itself nor on the heads of language users but more important than that is on its community of users who has experienced and has attached with it.

Saying it differently, findings of the previous studies have stressed on microlingustics errors. Despite the fruitfull of the studies, what is left is the examination of macrolinguitics errors. As such, the errors deal with socio- culture norms from which different communicative or linguistic norms might appear. Although the culture norms are something universally recognized, they are somewhat incorporated differently across cultures and are not expressed in the same linguistic forms which might lead to the so-called socio pragmatic errors.

Owing to the importance of an understanding toward the culture norms which also cause errors at most, this article, therefore, tries to shed light on macrolinguistics aspects that is sociopragmatic errors. The examination of such errors deals with using English of Indonesian speakers' daily conservation resulting from their common socio- culture norms. Furthermore, pedagogical implication of such errors in ELT would be also highlighted eventually as the expected conclusion of this article.

\section{Literature review}

Regarding the kinds, errors are classified into two main domains that are microlinguistics and macro linguistics errors. The former is concerned with pronunciation, grammatical and lexical use of language and the later deals with socio-cultural aspects, [21]. They are very distinctive on their own and might not be overlapping due to the coverage of each. The coverage, in this case, relies on the influencing factors in their natural environment or behavioural setting.

Yet, it is undeniable that the former in question can be fully understood as they may appear in any speech events both written and spoken resulting from linguistic transfer that is L1 to L2 [4]-[8], [13]. Meanwhile, the later deals with culture transfer L1 user to the culture of target language (L2). Putting it differently, the transfer process does not only occur on phonological, morphological and syntactical aspects (linguistic domain) but also goes along with culture aspect such as politeness and any pragmatic rules of language behaviour. As such, language and culture are intricately intertwined. Any time we successfully learn a language, we will also learn something of the speakers of that language [22]. Thus, the process of transferring language is definitely influenced by the culture of its speakers. This is like the same coin of having two different sides, one cannot be separated from the other.

Owing to the attachment of culture in language transfer, there is a need for someone to have both language and culture competence in his/her language production. Having insufficient knowledge of those two in question might lead to socio-pragmatic errors. On the other way around, the errors would not occur if there is a good competence which enables someone to use language productively [23]-[25]. In such a way, only of productive language use is facilitated and not the receptive one. 
In the meantime, it is worth mentioning that as a macrolinguitics coverage, socio-pragmatic errors (failures) deal with pragmatic rules of certain society or group of people. As such, what we accept as a good might be not for others, something which is more valuable in certain group of community might be considered as a common thing for others. As highlighted by [11], people in different societies or cultures speak differently because of their understanding toward linguistic behaviour which distinctively exists from one place to another Thus, the pragmatic rules of language user play vital roles in determining what and how the errors are.

Now pushing further, we often find the cases of communication breakdowns or deviations in the target culture and target language as the result of these errors [16], [24], [26], [27]. This is quite different from grammatical, syntactical and lexical errors which can be evaluated prescriptively. These errors concern with what are common and are acceptable in societies and what are not. In this respect, the acceptability is surely related to the context where they belong to [28]-[32]. This goes in line with the definition coined by [33]-[35] that pragmatic failure is the inability of using language effectively and of understanding what is meant by what is said.

It goes without saying that socio-pragmatic errors resulting from socio-culture norms might affect language behaviour. Second language or target language (L2) such as English learners are regarded as being intolerant, impolite, ignorant and unfriendly even, in fact, they are not and might be more than we perceive. This must be kept away to get the goal of communication by learning socio-culture norms of the target language (12) they learn.

Therefore, of greater importance in treating the errors is that the pedagogical implication in English Language Teaching (ELT). Aside from L1 [36]-[43], leaners should be taught to understand the culture of L2 [18], [19], [27], [44]-[47]. Having intercultural and pragmatic competence are the requirements for L2 leaners, particularly English learners, to put the language barriers away. Intercultural competence might help them to have culture adjustment regarding their English language performance.

\section{Research Methods}

This study mainly employed observation to gather the data. In this respect, the data were collected from Indonesian speakers' utterances found in their daily speech events. The collected data were analysed qualitatively using the interactive data analysis model of Miles et al. (2014). This data was reduced, displayed, and verified. Following the principles of conversation analysis (CA) and pragmatic theory supporting by some reviewed articles, the analysed data were discussed to have final conclusion.

\section{Results and Discussion}

As highlighted in introduction, the concern of this article is to shed light on Indonesian socio- pragmatic errors in using English that commonly found in daily context. The following data are the examples of such errors.
Data 1
Context : $\quad$ Thanking expression for helps
Ns : Thank you very much.
Indonesian : oh no, take it easy. It is my duty. 
The expression is uttered by the Indonesian as English non-native speaker (NNs) reflecting their understanding to Indonesian culture, and pragmatic rule of thanking expression. Meanwhile, the native speaker (Ns) might be confused regarding the response. And yet, for Indonesian people or probably in other Asian countries, the expression, which is a direct translation of "oh tidak, santai saja. Ini memang tugas saya", is quite common and shows honor and closeness to other people.

\section{Data II}

Context : The Ns (British man) is about to go to the station and looks for a taxi

Indonesian : Would you mind if I gave a ride to the station?

Ns $\quad$ : Why are you so kind to me?

Indonesian : Speechless (paralinguitics)

This dialogue indicates that the Indonesian (NNs) feel offended when the native speaker (Ns) responds the offering. To Indonesian, the response in question is like a suspicion and is considered as being impolite. Meanwhile, the native speaker (Ns), British man, considers that the question is something common to be raised for the person that he/she has never known in advance. Indeed, this happens because of cultural aspect that he/she has. The concept of directness and indirectness is the key factor of this misunderstanding [48]. It might be acceptable if the British (Ns) uses indirectness to respond the offering. However, He, the native speaker (Ns), is not accustomed to being in that way or going around the bush. Directness is his culture.

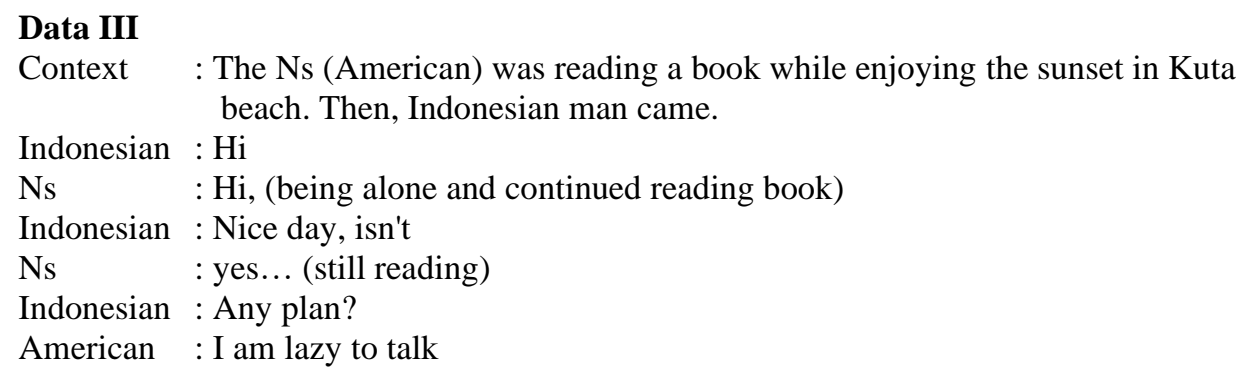

This conversation seems so embarrassing. The communication breaks down just because of having socio-cultural errors or pragmatic failures. In this context, Indonesian expresses his politeness for the sake of a companion. He shows his intimacy by accompanying and talking no matter the situation is. As such, politeness is viewed as an utterance level phenomenon as the Indonesian just focuses on linguistic form and his own context without referring to the interlocutor's context [49]-[52] causing him to be in socio-pragmatic errors.

On the other hand, the American does not prefer to do as Indonesian does. He likes to be alone as he enjoys reading and sitting in the beach without any companion. Saying "I am lazy to talk" is another way of saying "Leave me alone, please!" or even don't disturb me, please!". Implicitly, the interlocutor (American) concerns with the context and not on a linguistic form only (utterance level). In other words, both view politeness as a pragmatic rule differently.

\section{Data IV}

Context : A tour guide was with an Australian young lady in small caffee in the late evening

Indonesian : It is cold. Would you mind having a cup of tea? (Talking with Australian in the late evening)

Ns : : Oh, no thanks and uttered some rude words (run away) 
Indonesian : (Speechless and surprised)

This example indicates the pragmatic failure of the Indonesian, Non-native speaker (NNs) in offering a cup of tea to the Australian young Lady. Looking at the context, this dialogue occurred as they were in small coffee in the late evening. The situation was so quiet and was very cold. The Indonesian thinks that it is a good time to have tea because of the cold situation. Yet, referring to the context, the lady thinks of it differently. In the lady's pragmatic context, such offering is a request of having sexual intercourse as what she has in her country.

\section{Data V}

Context : Expressing gratitude is something universal and yet it is differently uttered as usually found in Indonesian and Ns context.

Indonesian : "Before closing my speech, I do apologize if all I said is inconvenient to you"

Ns : : That's all I can say "Thank you" or just directly say "Thank you" (English style)

Indonesian style of expressing gratitude is determined by the concept of Indonesian politeness. The expression above is a direct translation of sebelum saya mengakhiri, saya mohon maaf jika kata-kata saya tadi tidak berkenan. As such, saying that expression is a politeness strategy of the speaker to the audience. Socially and culturally, it is acceptable. Then, to translate this expression into English (not to explain translation errors), it is not really accepted due to having different social and cultural norms of realizing politeness value [53]-[56]. English native speakers never use such Indonesia style as their directness, but Indonesians prefer to utilize indirectness as politeness strategy which is reflected in their language production.

With regard to the examples mentioned, it is not unclear that socio-cultural adjustment tends to be at the peak level of achieving communication goal. Undeniably, intercultural and pragmatic competences are definitely required which can be reflected in the language usage. In a more profound sense, the goal of communication lies deeply on linguistic behaviour (wording) and social behaviour [25]. Therefore, it is important to look at what people really say and context in which the interaction takes place. Summing up, how is said is actually a part of what is said. Socio-cultural of the language users is very crucial to avoid the errors.

\section{Pedagogical implication in ELT}

It is noteworthy to say that socio-pragmatic errors, as a pedagogical topic, are the thorny and problematic issues. Having an impetus to cope with such issues, a teacher who has a vital role in English Language Teaching (ELT) should do something to solve or to avoid their students from making the errors. Interesting question might come up, is that "what is the pedagogical implication in treating such errors?

Although it is a very complex task, as a wise, sensitive and preceptive foreign or and second language teacher, deciding to treat the errors both implicitly and explicitly is something crucial to do. As such, it is done for the sake of good longevity of classroom atmosphere in terms of interpersonal relation and intimacy being built. Regardless the source of the errors, the way how the teacher copes with errors is of benefit to attain learning goals.

In a profound sense, a study on errors correction has not come yet to the conclusive methods or techniques. Yet, studies of [57], [58] shed light on the argument to differ between global and local errors. This might lead to certain consideration, in which, the teachers should decide to treat the errors. They suggest that it is not necessary for the teachers to correct the local errors. In this regard, the errors messages are still tolerable for the interlocutors and might not interrupt the flow of communication in meaning negotiation process. Meanwhile, global errors should be 
corrected since the messages remain confusion and misunderstanding to the interlocutors. At this point, teacher's correction should carry the message that errors are not bad. They are good indicators that innate language acquisition abilities are alive. Besides, it is an indication that the new language's aspects are developing.

Likely, as highlighted by [18], [19], [59], [60], the way how the teacher teaches the target language to his/her students is definitely considered to be the most important aspect in teachinglearning process. Since language is a part of the culture and both are interrelated, the teacher should also be able to provide a space in which the target culture is embedded. Putting it differently, in English language teaching-learning process, teacher should concern with ways of thinking, feeling, acting, customs, norms, and rules of its users. This might be beneficial to enhance communicative competence and intercultural understanding in integration, not as separate skills or competencies, [39]. In turn, pragmatic competence should be improved, particularly, the cultural awareness of English as target language (L2) as well as language sensitivity by learning the context. In this case, teachers should be more knowledgeable, resourceful and sensitive to make use of teaching materials (textbooks), learning instruction, and assessment process in the view of English as target language.

By no room of discussion, the importance of cultural context in English language teaching is undeniable. Along the line of this statement, the teaching paradigm shifting from teaching toward learning, forces a teacher to be aware of target culture's role in the classroom. What is taught is definitely and always related to target culture of the target language (English). As said by [46], [61], every lesson is about something and that something is cultural. As such, it is supported by [44], [62] who have implicitly claimed that there must be a requirement to learn the people and the culture if one wants to learn their language. Then, language cannot be learned independently without its culture and should go with the diversity, complexity, and the effect of context in the teaching-learning process.

It is strongly argued that the message of language does not exist in the language itself nor on language user's head but on its community, who has used it. This, implicitly, means that teaching and learning English as a target language, as previously mentioned, must include the culture. It should not only be limited to a linguistic form or in such lexicographic meaning (microlinguistics) but rather on the authencity of its socio- pragmatic meaning (macrolinguistics) [22]. By doing so, teaching has clearly defined itself as a problem -defined discipline, not a transformed-inciting information.

The socio-pragmatic aspects of the target language are considered as being subtle and complex. As a teacher, the lessons' goal is to teach such subtlety and complexity. The students will no longer be in the classroom. They should be prepared to be independent learners, language manipulators, and negotiators somewhere ahead out there. Summing up, it would be more advantageous and beneficial to integrate language and culture through authenticity and sociopragmatic language learning instruction.

\section{Conclusion}

Socio-pragmatic errors are the errors that occur as the result of L1 interference and insufficient knowledge of context and culture of the target language (L2). To solve these errors, knowledge and a good understanding of target language and target culture would be of benefit to cope with. This solution can be actualized by being sensitive to deciding the correction to learners' errors. The sensitivity is reflected in the way of what and how to teach along with the 
assessment process. Last but not least, teaching target language must be effective in the sense of how learning instruction is integrated with its culture.

\section{References}

[1] R. Ananda, S. A. Gani, and R. Sahardin, "A Study of Error Analysis from Students' Sentences in Writing,” Stud. English Lang. Educ., vol. 1, no. 2, pp. 81-95, 2014.

[2] S. B. Swasti, "An Error Analysis on the Use Of English Articles in Students' Written Descriptive Texts: A Case of Class X MIA 1 of SMA N 1 Binangun, Cilacap in the Academic Year 2014/2015," J. English Lang. Teach., vol. 5, no. 1, pp. 1-10, 2016.

[3] P. Kusumawardhani, "Error Analysis in Writing an English Narrative Composition," J. Ling. Cult. Vol.9, vol. 9, no. 2, 2015.

[4] S. Kalee, Y. Rasyid, and L. Muliastuti, "Error Analysis on the Use of Letters Students in Indonesian Papers Written by Thai Students,” J. English Lang. Stud., vol. 3, no. 1, pp. 113-124, 2018.

[5] N. T. Fitria, "Error Analysis Found in Students' Writing Composition of Simple Future Tense," ELS J. Interdiscip. Stud. Humanit., vol. 1, no. 3, pp. 240-251, 2018.

[6] T. J. Setiyorini, P. Dewi, and E. S. Masykuri, "The Grammatical Error Analysis Found in Students ' Composition,” Lensa Kaji. Kebahasaan, Kesusastraan, dan Budaya, vol. 10, no. 2, pp. 218-233, 2020.

[7] S. G. Dinamika and R. Hanafiah, "Syntactical Error Analysis on Report Text," J. Appl. Linguist. Lit., vol. 4, no. 2, pp. 120-129, 2019.

[8] Fadilah, "An Analysis of Error on the Use of Simple Past Tense in Writing Narative Text of 42 State SMKIn Jakarta," J. Bhs. dan Komunukasi, vol. 11, no. 1, pp. 15-24, 2019.

[9] H. K. B. Ginting, Rahmawati, and P. Purwanto, "Error Analysis on Using Simple Past Tense in Writing Recount Text at The Eighth Grade of SMP Bina Bersaudara 1 Medan,” J. Edulingua, vol. 6, no. 1, pp. 12-17, 2019.

[10] M. Salehi and A. Bahrami, "An Error Analysis of Journal Papers Written by Persian Authors," Cogent Arts Humanit., vol. 5, no. October, pp. 1-16, 2018.

[11] D. Stukan, "Sociopragmatic Failure: Struggling with Cross-Cultural Differences in Communication," Open J. Anthropol. Stud., vol. 2, no. 1, pp. 27-36, 2018.

[12] S. Darus, "Error Analysis of the Written English Essays of Secondary School Students in Malaysia: A Case Study," Eur. J. Soc. Sci., vol. 8, no. 3, p. 2009, 2014.

[13] T. N. Fitria, "Spelling Error Analysis in Students' Writing English Composition," J. GEEJ, vol. 7, no. 2, pp. 240-254, 2020.

[14] J. Liu, "Adaptation of Authentic Materials in English Listening Comprehension Classes," heory Pract. Lang. Stud., vol. 6, no. 9, pp. 1774-1779, 2016.

[15] Z. Liu, "Error Analysis in article," Int. Symp. Soc. Sci. (ISSS, pp. 367-372, 2015.

[16] M. S. Al Zoubi, "The Significance of Error Analysis in Written Production: A Case Study of Ajloun National University Students,” Int. J. English Lang. Lit. Stud., vol. 7, no. 4, pp. 150-159, 2018.

[17] C. D. Nguyen, "Connections between Learning and Teaching: EFL Teachers ' Reflective Practice," Pedagog. An Int. J., vol. 12, no. 3, pp. 237-255, 2017.

[18] K. Lindahl and N. M. Watkins, "Creating a Culture of Language Awareness in Content-Based Contexts," Tesol J., vol. 6, no. 4, pp. 777-789, 2015.

[19] G. Couper and A. Watkins, "Teaching the Sociocultural Norms of an Undergraduate Community of Practice," Tesol J., vol. 7, no. 1, pp. 4-39, 2016.

[20] B. Siefert, S. Salas, and M. M. D. Amico, “" I Understand the Struggle ': Leveraging the Lived Experiences of African American Teachers in TESOL," Tesol J., vol. 6, no. 4, pp. 731-750, 2015.

[21] E. Kadarisman, From Description to Explanation: Essays in Linguistics and Applied Linguistics. Linguistic Society of Indonesia, 2015.

[22] H. D. Brown, Teaching by Principle and Interactive Approach to language pedagogy. New York: Longman Inc., 2001.

[23] N. Gunduz, "Sociopragmatic Elements and Possible Failure in EFL Teaching," Dil Derg. • Sayi, vol. 167, no. 1, pp. 49-66, 2016. 
[24] T. Saleem, U. Anjum, and S. Tahir, "The Sociopragmatic and Pragmalinguistic Strategies in L2 Pragmatic Competence : A Case of Pakistani ESL Learners,” J. Intercult. Commun. Res., vol. 50, no. 2, pp. 1-22, 2021.

[25] W. Zhu, "Polite Requestive Strategies in Emails : An Investigation of Pragmatic Competence of Chinese EFL Learners," RELC J., vol. 43, no. 2, pp. 217-238, 2012.

[26] I. Syahri and R. Susanti, "An Analysis of Local and Target Culture Integration in the English Textbooks for Senior High School in Palembang," J. Educ. Hum. Dev., vol. 5, no. 2, pp. 97-102, 2016.

[27] R. Marhamah, B. Daud, and I. A. Samad, "Integrating Target Language Culture into TeachingLearning EFL,” ENGLISH Educ. J. (EEJ, vol. 4, no. 488-502, 8AD.

[28] S. C. Brown, P., \& Levinson, Universals in language usage: Politeness phenomena. In E. N. Goody (Ed.), Questions and politeness: Strategies in social interaction (pp. 256-289). Cambridge, UK: Cambridge University Press., 1978.

[29] J. L. Mey, "Pragmatics: An Introduction. Blackwell Oxford \& Cambridge USA." p. 221, 1993.

[30] G. Yule, "Pragmatics." Oxford, UK: Oxford University Press, 1996.

[31] H. R. M. Iv and F. B. Tenore, "Classroom Management in Diverse Classrooms," Urban Educ., vol. 45, no. 5, pp. 560-603, 2010.

[32] Y. S. Mahmud, "The Representation of Local Culture in Indonesian EFL Textbooks: Rationales and Implications,” Indones. EFL J., vol. 5, no. 2, pp. 61-72, 2019.

[33] N. Taguchi, "The Effects of Practice Modality on Pragmatic Development in L2 Chinese," 2012.

[34] N. Taguchi and B. H. Cmu, "Pragmatic Development as a Dynamic , Complex Process : General Patterns and Case Histories," Mod. Lang. Journa, vol. 95, no. 4, pp. 605-627, 2011.

[35] N. Taguchi, F. Xiao, and S. Li, "Effects of Intercultural Competence and Social Contact on Speech Act Production in a Chinese Study Abroad Context," Mod. Lang. Journa, vol. 100, no. 4, pp. 1-22, 2016.

[36] A. Nicholas, "A Concept-based Approach to Teaching Speech Acts in the EFL Classroom,” ELT J. Vol., vol. 69, no. 4, pp. 383-394, 2015.

[37] C. A. Hafner, "Remix Culture and English Language Teaching: The Expression of Learner Voice in Digital Multimodal Compositions," Tesol J., vol. 49, no. 3, pp. 486-509, 2015.

[38] G. Motteram, "Membership , Belonging , and Identity in the Twenty-first Century," ELT, vol. 70, no. 2, pp. 150-159, 2016.

[39] N. S. Snodin, "Rethinking Culture Teaching in English Language Programmes in Thailand," RELC J., vol. 47, no. 3, 2015.

[40] H. Richards, C. Conway, A. Roskvist, and S. Harvey, "Foreign Language Teachers ' Language Proficiency and Their Language Teaching Practice,” Lang. Learn. J., vol. 41, no. 2, pp. 231-246, 2013.

[41] A. Alamsyah, "Unika Atma Jaya, 6-8 April 2016," in The Use of Local Short Story in English Language Learning (A Literary Review on The Use Of Local Sources As An Alternative Teaching Media In Efl), 2016, no. 6-8 April, pp. 286-290.

[42] I. A. Kuntoro, C. C. Peterson, and V. Slaughter, "Culture, Parenting, and Children 's Theory of Mind Development in Indonesia,” J. Cross. Cult. Psychol., vol. 48, no. 9, pp. 1389-1409, 2017.

[43] Sugirin, S. Sudartini, Suciati, and L. Nurhayati, "A Study on Cultural Integration in the English Textbooks for Junior High Schools," Litera, vol. 10, no. 2, pp. 235-246, 2011

[44] W. Yang and H. Li, "Changing Culture, Changing Curriculum : A case Study of Early Childhood Curriculum Innovations in Two Chinese Kindergartens," Curric. J., vol. 30, no. 3, pp. 1-19, 2019.

[45] C. Miska, I. Szőcs, and M. Schiffinger, "Culture's Effects on Corporate Sustainability Practices : A Multi-domain and Multi-level view," J. World Bus., vol. 53, no. 2, pp. 263-279, 2017.

[46] M. M. . Mahmoud, "Culture and English Language Teaching in the Arab World," Adult Learn., vol. 25, no. 3, pp. 66-72, 2015.

[47] Z. Tajeddin and M. Pezeshki, "Acquisition of Politeness Markers in an EFL Context : Impact of Input Enhancement and Output Tasks," RELC J., vol. 45, no. 3, pp. 269-286, 2014.

[48] S. Yazdanfar and A. Bonyadi, "Request Strategies in Everyday Interactions of Persian and English Speakers," SAGE Open, no. October-December, pp. 1-11, 2016. 
[49] R. Ningsih, E. Boeriswati, and L. Muliastuti, "Language Politeness of Students and Teachers: An Ethnographic Study,” Getsempena English Educ. J., vol. 7, no. 1, pp. 159-169, 2020.

[50] Nashruddin, F. A. Alam, and A. Harun, "Moral Values Found in Linguistic Politeness Patterns of Bugis Society," Edumaspul - J. Pendidik., vol. 4, no. 1, pp. 132-141, 2020.

[51] G. Leech, "Principle of Politeness." Longman, London, England, 1983.

[52] M. Economidou-kogetsidis, "Teaching Email Politeness in the EFL / ESL Classroom," ELT J., vol. 69, no. 4, pp. 415-424, 2015.

[53] V. D. H. (2010) Ahmadian MJ, "A comparative study of perception of politeness of American reprimands by Iranian EFL learners and Americans," Soc. Sci., vol. 5, pp. 359-63, 2010.

[54] S. Tamimi Sa'd and M. Mohammadi, "A cross-sectional study of Iranian EFL learners' polite and impolite apologies Seyyed,” J. Lang. Linguist. Stud., vol. 10, no. 1, pp. 119-136, 2014.

[55] Watts R.J., "Key Topics in Sociolinguistics: Politeness." 2003.

[56] S. Lakoff and Ide, Broadening the horizon of linguistic politeness. In: Lakoff R, Ide S (eds) Broadening the Horizon of Linguistic Politeness. Amsterdam: John Benjamins, 2005.

[57] S.-Y. Choi and S. Li, "Corrective Feedback and Learner Uptake in a Child ESOL Classroom,” RELC J., vol. 43, no. 3, pp. $331-351,2012$.

[58] H. Sarandi, "Oral Corrective Feedback: A Question of Classification and Application," Tesol Q., vol. 50, no. 1, pp. 235-246, 2016.

[59] H. Limberg, "Principles for Pragmatics Teaching : Apologies in the EFL Alassroom," ELT J. Vol., vol. 69, no. 3, pp. 275-285, 2015.

[60] Z. Tajeddin, "Interlanguage Pragmatic Motivation: Its Construct and Impact on Speech Act Production," RELC J., vol. 43, no. 3, pp. 353-372, 2012.

[61] A. Siegel, "What should we talk about? The authenticity of textbook topics," ELT J., vol. 68, no. 4, pp. 363-375, 2014.

[62] T. B. Tin, "A look into the local pedagogy of an English language classroom in Nepal," Lang. Teach. Res., vol. 18, no. 3, pp. 397-417, 2014 